DZIEJE NAJNOWSZE, ROCZNIK XLVII - 2015, 2

PL ISSN 0419-8824

\author{
Ewa Kowalska \\ Warszawa
}

\title{
Osadnictwo rolne ludności żydowskiej na Ukrainie w latach 1924-1934 (uwagi ogólne)
}

Losy ludności żydowskiej w Rosji i później w Związku Sowieckim stanowią szczególną kartę w historii tego państwa. Jedną z mniej znanych stron jest zwłaszcza osadnictwo rolne tej mniejszości, dotąd szerzej nieopracowane. Zamierzone krótkie ujęcie tematu stanowi próbę uzupełnienia choć w małej części istotnej luki w historiografii byłych obywateli Rzeczypospolitej, którzy na skutek zmiany granic znaleźli się w Rosji, a później w Związku Sowieckim. Podjęcie tego zagadnienia wymusza refleksje nad kwestiami: o przyczyny akcji osadnictwa rolnego ludności żydowskiej, o regulacje prawne, które zadecydowały o życiu codziennym kolonii, o przepisy, które umożliwiły dostęp do nich organizacji zagranicznych, i wreszcie o przyczyny załamania osadnictwa żydowskiego na Ukrainie. Poruszone zagadnienia zmuszają do zastanowienia, czy osadnictwo rolne narodu wybranego w ZSRS należy uznać tylko za krótki okres urzeczywistnienia jego wielkich nadziei w sowieckiej historii, co po sobie ten czas pozostawił - czy tylko świadomość skazania tej mniejszości na wyobcowanie, czy może problem o wiele bardziej skomplikowanych wyznaczników, łamiących rozmaite stereotypy?

Powstałe po 1917 r. państwo sowieckie stało się spadkobiercą imperium carskiego, którego przestrzeń geopolityczną, rozsadzoną przez rewolucję i wzbudzone przez nią ruchy emancypacyjne, bolszewicy zamierzali utrzymać i zharmonizować. Zespolić tak, aby poszczególne społeczności przyjęły jeden, wspólny, sowiecki system wartości, norm i ocen.

Wśród narodów objętych integracyjną polityką narodowościową szczególne miejsce zajęła ludność żydowska. Do tej mniejszości nie przystawała bowiem sowiecka definicja narodu ani nie dawało się jej podporządkować żadnej z klas. Jej społeczna struktura, wyróżniająca się znacznym udziałem drobnych kupców i rzemieślników, wyraźnie odbiegała od sowieckiego modelu państwa robotników i chłopów ${ }^{1}$. Swoistość jej położenia wynikała też z uczestnictwa we władzy wielu działaczy żydowskich i prawie $3 \mathrm{mln}$ Żydów żyjących w ich

\footnotetext{
${ }^{1}$ Żydzi byli w Rosji narodem szczególnym pod względem dotyczącego ich obostrzenia zakupu bądź dzierżawy ziemi poza granicami miast i miasteczek. W rezultacie w kraju, w którym rolnicy stanowili 86 proc. ogółu ludności, tylko niewielka część tej mniejszości zajmowała się uprawą roli. W świetle danych statystycznych spośród Żydów przebywających w Rosji tylko 5 proc. zajmowało się rolnictwem, 10 proc. było przedstawicielami różnych profesji, m.in. urzędnikami państwowymi, 15 proc. — robotnikami, a 70 proc. stanowiło masę drobnych kupców i ludzi bez zajęcia. Ten stan rzeczy zaczął się
} 
złowieszczym cieniu, otoczonych etnicznie, religijnie lub społecznie motywowaną niechęcią i podejrzliwością wielu grup mieszkańców ZSRS ${ }^{2}$.

Elementem integracyjnej polityki narodowościowej była rolna akcja osiedleńcza ${ }^{3}$. Postanowiona przez CK RKP(b) (Komitet Centralny Radzieckiej Partii Komunistycznej (bolszewików) w 1924 r. akcja kolonizacyjna miała sprzyjać uformowaniu się w społeczności żydowskiej warstwy chłopskiej, a więc transformacji jej społecznego charakteru i kultury w kierunku zespolenia z wielonarodowym społeczeństwem sowieckim ${ }^{4}$.

Pozbawionych środków do życia w wyniku wojny domowej i pogromów na początku lat dwudziestych było 30 tys. Żydów, nazywanych izbytocznoje nasielenije. Aby zmienić ich ciężką sytuację bytową i jednocześnie ich ,uproduktywnić”, postanowiono przesiedlić tę mniejszość na stepową część Ukrainy, gdzie znajdowały się pozostałe po nadzieleniu chłopów ukraińskich wolne ziemie uprawne.

29 VII 1924 r. zgodnie z postanowieniem Ogólnoukraińskiego CIK (Centralnego Komitetu Wykonawczego) rozpoczęła się oficjalna kampania mająca na celu rozpropagowanie wśród ludności żydowskiej osadnictwa rolnego. Należy dodać, iż jeszcze przed wydzieleniem funduszów ziemskich od początku 1924 r. osiedliło się w rejonie Krzywego Rogu i zaczęło uprawiać ziemię 250 rodzin żydowskich ${ }^{5}$. W tym okresie przejściowym były one jednak zdane na zrządzenie losu, na własne siły i zdolność obrony przed niechętnym otoczeniem. Dopiero z początkiem regulowanego przez państwo etapu akcji osiedleńczej żydowscy przesiedleńcy rolni otrzymali oficjalny status prawny i mogli liczyć na pomoc i obronę państwa.

stopniowo zmieniać dopiero po rewolucji październikowej. Archiwum Akt Nowych (dalej AAN) MSZ, 2288, k. 145.

${ }^{2}$ Mówiąc o znacznym odsetku Żydów na wyższych stanowiskach, trzeba wskazać na mechanizmy władzy, która wykorzystuje mniejszości do pracy w organach represji jako „ludzi z innej gliny”, którym łatwiej stawać przeciwko członkom większości. Efektem tej prawidłowości był znaczny udział w aparacie władzy nie tylko Żydów, ale też np. Łotyszy i Polaków.

${ }^{3}$ Wypada uzupełnić, iż osadnictwo rolne ludności żydowskiej na Ukrainie nie było nowatorskim pomysłem władz sowieckich, lecz sięgało XIX w. Już w czasach carskich „problem żydowski”, powstały na skutek przyłączenia ziem Rzeczypospolitej tzw. czerty osiedtosti (strefy osiedlenia), starano się rozwiązać m.in. przez osiedlenie na ziemi wielu tysięcy osób tej narodowości. Choć skala akcji była niewielka (180 tys. gospodarstw zgrupowanych w 38 koloniach i 163 mniejszych osiedlach rolniczych uprawiających obszar ponad 82 tys. dziesięcin), można powiedzieć, iż mniejszość żydowska zdobyła $\mathrm{w}$ carskim imperium pierwsze doświadczenia w gospodarowaniu.

${ }^{4}$ W końcu 1921 r. w Moskwie obradował Ogólnorosyjski Zjazd Kołchozów i Sowchozów. W jego organizację zaangażowana była pierwsza w ZSRS żydowska organizacja społeczna, Związek Żydowskich Mas Pracujących (Sojuz Ewrejskich Trudjaszczichsja Mass - Setmass), która zainicjowała pracę nowych żydowskich arteli i komun rolniczych. W rezolucji zjazdu odnotowano: „Jednym ze środków produktywizacji żydowskich mas jest ich agraryzacja w drodze zakładania arteli [...] najlepszym potwierdzeniem [słuszności tej tezy] są istniejące żydowskie artele i komuny. Po tej rezolucji, na osobiste polecenie Włodzimierza Lenina, Szymon Dimansztejn (przewodniczący żydowskiego komisariatu przy Narkomnace - Narodowym Komisariacie Narodowości) oraz Szmuel Zydowiecki (przewodniczący Rosyjskiego i Ukraińskiego biura Setmass) przygotowali referat, po wysłuchaniu którego Komitet Centralny (CK) uznał za pożądane zajęcie się przez masy żydowskie uprawą roli”, „Nakanunie”, nr 12-13, 15 III 1921, s.16; J. W. Golde, Zemelnoe ustrojstwo trudjaszczichsja ewreew, Moskwa 1925, s. 4.

O wadze, jaką kierownictwo polityczne ZSRS przywiązywało dla spraw ludności żydowskiej i jej transformacji socjalnej, najlepiej świadczy działanie przy KC RKP(b) specjalnej sekcji do spraw żydowskich - Jewsiekcij.

${ }_{5}$ Centralnyj Gosudarstwiennyj Archiw Wysszich Organow Własti i Gosudarstwiennogo Uprawlienija Ukrainy (dalej CGAWO), f. 413, op. 1, d. 10, 1. 66. 
Praktyka przesiedleń rolniczych przewidywała:

- rozpoznanie rejonu przesiedlenia,

- przedyskutowanie problemów związanych z przesiedleniem z organami władz miejscowych,

- formalne spisanie porozumień,

- przejazd przesiedleńców

Przyszli rolnicy, ,chodoki”, jak ich nazywano, z wyprzedzeniem byli uprzedzani o przejeździe na wolne ziemie. Po zarejestrowaniu decydujących się na pracę na roli byli oni formowani w kolektywy i otrzymywali ,chodaczeskije” dokumenty. Były to zaświadczenia, że dany człowiek jest członkiem przyszłego kolektywu lub towarzystwa rolnego, ma status prawny i jest chroniony przez państwo. Oprócz tego wszystkie organy władz miejscowych w rejonach przesiedlenia były zobowiązane doradzać przesiedleńcom w wyborze dogodnych ziem. „Chodaczeskije” zaświadczenia obowiązywały przy nadawaniu małych działek z kolonizacyjnych rezerw w oznaczonych guberniach. Dokumenty te były ważne przez dwa miesiące od dnia wystawienia. Do czasu powrotu ,chodoka” $\mathrm{z}$ adnotacją o zarejestrowaniu przez niego nadziału ziemi nie była dopuszczalna likwidacja jego gospodarstwa w miejscu poprzedniego zamieszkania.

Każdy kandydat na rolnika miał czas do 1 sierpnia następnego roku na przesiedlenie się na zarejestrowaną ziemię. Trzeba dodać, iż po upływie tego terminu tracił prawo do zarejestrowanego nadziału gruntu. Zabronione też było na skutek rozmaitych dróg losowych, np. nieszczęśliwego wypadku, przekazywanie zarejestrowanej działki innym osobom nieuwzględnionym w zaświadczeniu. Po przybyciu na przydzieloną ziemię ,chodaczeskoje” zaświadczenie było zastępowane tymczasowym dokumentem przesiedleńczym w okręgowym oddziale ziemskim. Po spełnieniu tych formalności przesiedleniec stawał się pełnoprawnym właścicielem zarejestrowanej działki ziemi.

Liczebność tzw. zbędnej ludności przewidzianej do akcji przesiedleńczej na Ukrainie sięgała aż $5 \mathrm{mln}$. Wszyscy mający podjąć pracę na roli musieli jednak spełniać określone warunki wyznaczone przez władze. Od przesiedleńców wymagano np., aby w rodzinie złożonej z pięciu członków były co najmniej trzy osoby pracujące. Jednocześnie każda rodzinna powinna mieć nie mniej niż 500 rubli na zagospodarowanie. Jedynie dla Żydów zrobiono kilka wyjątków odnośnie do zestawu rodziny i jej zabezpieczenia finansowego.

Zgodnie z wytycznymi od Żydów mających liczne rodziny wielopokoleniowe wymagano, aby z rodziny pracowały nie mniej niż dwie osoby. Norma przydziału ziemi na pięcio- sześcioosobową rodzinę wynosiła na największych dwóch obszarach akcji osiedleńczej: w obwodzie chersońskim — 15 des., Krzywego Rogu - 12 des $^{6}$. Jednocześnie, uwzględniając liczniejsze rodziny, zastrzegano, że przydziały gruntów nie mogą przekroczyć na Chersoniu - 27,5 des., a w okolicach Krzywego Rogu — 18 des.

W celu rozeznania wielkości kosztów, jakim będzie zmuszone podołać państwo, udzielając kredytu kolonizacyjnego przesiedlanym, rodziny podzielono na pięć kategorii: te, które miały 100 rubli na zagospodarowanie, 150, 300, 500 i te najzamożniejsze, które mogły się przesiedlić na własny koszt. Z 1696 rodzin, które zarezerwowały ziemię na terenach Krzywego Rogu w 1925 r., 10-150 rubli miało 66 proc., 20 proc. z nich miało 300 rubli, a tylko 9 proc. - 500 rubli. Pozostałe 5 proc. rodzin mogło się przesiedlić na własny koszt. Przytoczone dane najlepiej obrazują, iż uprawą roli miała się zajmować w większości biedna część społeczności żydowskiej, której była potrzebna pomoc ${ }^{7}$.

${ }^{6}$ Dziesięcina, ówczesna miara powierzchni równa 1,0925 ha.

${ }^{7} \mathrm{Na}$ Ukrainie przeprowadzono dwie rejestracje chętnych do pracy na roli; w 1925 i w $1926 \mathrm{r}$. W $1925 \mathrm{r}$. zarejestrowano 15 tys. chętnych, a w następnym ponad 70 tys. $Z$ tej liczby 10 tys. stanowili robotnicy, 
Interesująca była forma kierowania dzieloną ziemią. Na czele każdego funduszu ziemskiego stał agronom, który odpowiadał za wykonanie wszystkich prac, poczynając od budownictwa mieszkaniowego i gospodarczego, przez kredytowanie gospodarstw, buchalterię, organizację wewnętrzną, aż po sprawy sporne w pracy. Agronom był jedyną osobą karaną prawnie za wszelkie poczynania grupy. Jego duża odpowiedzialność wiązała się zwłaszcza ze współpracą z amerykańską organizacją Agro-Joint, która za przyzwoleniem władz najwyższych niezwykle aktywnie od lipca 1924 r. współuczestniczyła w rolnej akcji osiedleńczej ludności żydowskiej ${ }^{8}$.

W 1925 r. planowano na Ukrainie przesiedlić 3 tys. rodzin żydowskich. Już jednak na początku roku na samej Chersońszczyźnie osiedliło się 2240 rodzin. Część z nich zamieszkała w 600 przygotowanych dla nich domach. Zaczęły one uprawiać ziemię o łącznej powierzchni 36653 dziesięcin. W rejonie Krzywego Rogu rodziny żydowskie z początkiem roku zajęły obszar 7200 des. Do końca 1925 r. ogółem zarejestrowano 15 tys. żydowskich rolników, którzy przybyli na miejsce już sformowanymi kolektywami.

Gospodarcza rzeczywistość przesiedlanych była znacznie trudniejsza, niż to wynikało z wcześniejszych deklaracji władz. Przygotowania do wiosennych zasiewów zaczęły się ze znacznym opóźnieniem. Rolnicy byli niedostatecznie zaopatrzeni w żywy inwentarz, zwłaszcza w zwierzęta pociągowe: konie, woły czy nawet krowy. Zgodnie z deklaracjami ukraiński KOMZET, czyli Komitet po ziemielnomu ustrojstvu jewriejskich trudjaszczichsja (Komitet Osadnictwa Ziemskiego Żydów Pracujących), miał zapewnić dostarczenie żywego inwentarza dla osiedleńców. Najbiedniejsi mieli dostawać konie i krowy na kredyt. W praktyce przydział inwentarza nie pokrywał zapotrzebowania i w związku z tym dochodziło do rozmaitych paradoksów. Nierzadko się zdarzało, że jedna krowa przypadała na dwie lub więcej rodzin. W związku z brakiem właściciela były problemy z jej utrzymaniem. Bez przydziału przyznawanego wyłącznie jej posiadaczowi żadna z rodzin nie miała karmy i krowa mogła paść z głodu. Do utrudnień związanych z nielogicznością dnia codziennego dochodziła sytuacja psychologiczna: brak nawyku do pracy na roli, przerażenie wywołane brakiem potrzebnych umiejętności oraz nieznane, nie zawsze przychylne otoczenie społeczne. Mimo niedostatków i rozmaitych przeciwności losu wysiłek osiedleńców włożony w zagospodarowanie był ogromny. Najlepiej świadczą o nim wyniki inspekcji gospodarstw żydowskich przeprowadzonej przez Centralną Komisję Mniejszości Narodowych Ukrainy (CK Nacmien). 73 kolektywy na Chersoniu, złożone z 942 rodzin, obsiały ponad 4 tys. des. Na 1195,75 des. tej ziemi posiano pszenicę i jęczmień, na 1754,25 des. — kukurydzę, arbuzy, słoneczniki i zasadzono kartofle, a 1500 des. obsiano prosem. Te uprawy, nie licząc ogórków - 942 des. - dawały na żydowską rodzinę 4,6 des. zagospodarowanej ziemi.

urzędnicy i chałupnicy, ponad 3 tys. kupcy, a pozostałą większość pracownicy wolnych zawodów i bezrobotni.

${ }^{8}$ Joint (pełna nazwa - Amerikanskij obedinennyj ewrejskij komitet po raspriedieleniju fondow Amerykański Zrzeszony Żydowski Komitet Rozdzielania Funduszy) powstał w wyniku połączenia trzech organizacji: Amerykańskiego Żydowskiego Komitetu Pomocy, Centralnego Komitetu Pomocy i Narodowego Komitetu Pomocy. Został założony 27 XI 1914 r. w wyniku inicjatywy bankiera i filantropa Felixa Warburga oraz działaczy społecznych: Louisa Marshalla czy Jacoba Schiffa. Przez pierwsze lata pomagał przede wszystkim Żydom, ofiarom pierwszej wojny światowej na terenach Rosji i Austro-Węgier. Następnie w latach 1919-1920 udzielał wsparcia ofiarom pogromów na terenach Polski i Ukrainy. 1 XI 1923 r. Joint zaprzestał działalności, a jego miejsce zajął Agro-Joint. Organizacja, planując długoterminową działalność charytatywną, ukierunkowała fundusze przede wszystkim na wspieranie rozpoczętej przez państwo sowieckie akcji osadnictwa rolnego ludności żydowskiej. 
W tym okresie taka powierzchnia zasiewów przewyższała średnią normę powierzchni zasiewów na Ukrainie? .

Wyrazem docenienia przez ukraińskie władze centralne wielkiego zaangażowania żydowskich rolników była decyzja o zakupieniu dla nich siedemnastu traktorów. Maszyny te zaczęły pracę w polu wiosną 1926 r. Jednak szybko się okazało, że pełne wykorzystanie mocy traktorów odbiega od oczekiwań. Kierowcy przeszli bowiem zaledwie sześciotygodniowe przeszkolenie. Ich umiejętności były zatem niewielkie. Dodatkowo wiele czasu zajmowały wyjazdy po paliwo, którego baza znajdowała się w centrum rejonu. Ponadto nie była zorganizowana regularna dostawa wody, niezbędna do pracy maszyn. W rezultacie traktory obrabiały dziennie tylko 1 des. ziemi. Należy też dodać, iż traktorzyści otrzymujący dzienną zapłatę nie byli zainteresowani większym wysiłkiem. Ich brak umiejętności oraz solidności w pracy nierzadko stawał się przyczyną okresowych przestojów w pracach polowych.

Żydowscy przesiedleńcy, chcąc jak najszybciej wykonać roboty na przydzielonych gruntach, podjęli decyzje na zebraniach kolektywów o zaniechaniu nieracjonalnego wykorzystania techniki. W rezultacie kroków podjętych przez władze wyższe zespoły traktorowe wraz z bazami remontowymi zostały przekazane przesiedleńczym kolektywom. Na efekty nie trzeba było długo czekać. Wkrótce zaczęła wzrastać wydajność pracy traktorzystów — w ciągu dziesięciogodzinnego dnia pracy obrabiali 2-3 des. ziemi.

Należy dodać, że używanie traktorów w pracach polowych przez żydowskich przesiedleńców wręcz porażało miejscową ludność, która nigdy dotąd nie widziała zastosowania na roli takich maszyn. Osłupienie wywoływało zarówno zazdrość, jak i szacunek. Traktory były synonimem prestiżu odzwierciedlającego w oczach miejscowych rolników stosunek władz do nowych osadników. Można wręcz mówić o mitologii traktoru będącego zarówno narzędziem władzy, jak też wyrazem skoku kulturowego i cywilizacyjnego.

Przedstawiciel Agro-Joint, organizacji, która między innymi zaopatrywała nowych osadników w maszyny rolnicze, prof. A. Fabrikant, starając się zobrazować podejście Żydów do pracy na roli, pisał: „Niezwiązani rutyną i przebrzmiałymi tradycjami nowi rolnicy żydowscy na miarę swoich sił i możliwości starali się wnieść w swoje gospodarstwo rozwój techniczny. Otwarty umysł, wrodzona przedsiębiorczość i kulturowe nawyki mieszkańców miast pozwalały na szybkie przyswojenie rozmaitych porad gospodarczych. Rzadko gdzie można spotkać takie zainteresowanie pracą rolniczą jak w grupie żydowskiej. Każda akcja oświatowa, spotkanie w sprawach rolnych lub budowa biblioteki rolniczej znajduje żywe zainteresowanie i traktowana jest z należytą uwagą"10.

Wypada odnotować, iż polityka władz sowieckich zmierzająca do ,produktywizacji” ludności żydowskiej, przekształcenia zawodowego, w tym przede wszystkim jej ,,agraryzacji”, była zgodna $\mathrm{z}$ tendencjami występującymi wówczas $\mathrm{w}$ środowisku międzynarodowych organizacji żydowskich, m.in. Jointu. W związku z brakiem państwowych środków pieniężnych wykonanie odgórnie ustalonych planów stało się możliwe w znacznym stopniu dzięki pomocy finansowej pochodzącej z zewnątrz, zwłaszcza od amerykańskiej organizacji Agro-Joint. Ona to wzięła na siebie większość kosztów zaopatrzenia nowych osiedleńców w traktory i maszyny rolnicze, budowę studni oraz domów, jak też łożenie na funkcjonowanie towarzystw kredytowych finansujących rozmaite kierunki działalności. Według dokumentów tej organizacji pomagała ona kolonistom średnio w wymiarze $2 \mathrm{mln}$ rubli rocznie ${ }^{11}$.

${ }^{9}$ CGAWO, f. 413, op. 1, d. 10, 1. 14.

${ }^{10}$ Ibidem, f. 413, op. 1, d. 10, 1. 70

${ }^{11}$ Owocem podobnej polityki były kibuce tworzone z przybyszów w Palestynie. 
Największym pod względem wielkości powierzchni kolonizacji żydowskiej w rejonie Krzywego Rogu był fundusz ziemski w rejonie nikopolskim. Cała ziemia o powierzchni ponad 26 tys. des. była podzielona na dwadzieścia dziewięć części. Na jedną rodzinę przypadało około 13 ha ziemi. Wykorzystywano najnowszą wówczas technologię sześciopolówki, z klinem przeznaczonym na żywienie zwierząt, co sprzyjało urodzajom i rozwiązywało problem paszy. Jako ziemię orną przesiedleńcy wykorzystywali aż 75 proc. gruntów, pozostałą część pod zabudowę. Liczba domów w każdej osadzie wahała się od dwudziestu siedmiu do sześćdziesięciu.

Wiosną 1926 r. na Chersoniu istniało już 191 żydowskich kolektywów skupiających 1751 rodzin nowej fali kolonizacji. Kolektywy te zasiały zboża ozime i jare jesienią 1925 i wiosną 1926 r. na obszarze 12 665, 5 des., co daje 7,2 des. na rodzinę. Wiele wysiłku włożono też w przygotowanie plantacji winogron. Zasadzono 50 tys. sadzonek na obszarze 28 des. Na wiosnę zamówienie zwiększono do 30 tys. Według sprawozdań szczególnie dobre gatunkowo sadzonki były dostarczane przez Agro-Joint.

Przedstawiony powyżej, niemal w sposób statystyczny, wzrost liczebności rolników żydowskich oraz przeprowadzonych przez nich zasiewów to najlepszy dowód na twierdzenie, iż przesiedleńcy poważnie myśleli o pracy na roli. Obala to powszechne wówczas pomówienia o tymczasowości żydowskiego zainteresowania ziemią i o szybkie masowe ucieczki z gospodarstw. Źródłem tych twierdzeń były powroty rodzin żydowskich niemających domów do poprzednich miejsc zamieszkania na okres zimy. Ich czasowe wyjazdy służyły również do rozniecania nastrojów antyżydowskich. Obwiniano ich m.in. o porzucanie ziemi, budując podwaliny pod pokazanie fiaska żydowskiej polityki osiedleńczej.

Wbrew krążącym pogłoskom powrót Żydów na wiosnę na swoje grunty i staranne tworzenie podstaw przyszłego gospodarstwa sprzyjało zmianie początkowo negatywnego stosunku ludności miejscowej do nowych osadników. Nie bez znaczenia w przeobrażaniu się ich postrzegania była też pomoc udzielana przez przybyszów rolnikom innych narodowości. Po obrobieniu swoich gruntów Żydzi nierzadko pracowali na polach sąsiadów, wykorzystując m.in. traktory i inną będącą w ich dyspozycji technikę. Ewolucja postaw była tym bardziej znacząca, że w tym okresie emocje budził np. problem „Pokrowskiego dieła”, „Trostjaneckiego”, „Kaniewskiego”. Były to konflikty wynikające z przywłaszczenia ziemi ,porzuconej” przez osadników żydowskich przez ludność miejscową. Przykłady można mnożyć: w październiku 1925 r. gospodarze w rejonie borysławskim samowolnie zajęli około 370 des. ziemi przeznaczonej dla nowych osiedleńców, tak samo postąpili gospodarze w rejonie kristowozdwiżenskim, zajmując obszar 250 des. ziemi. Żydzi, próbując temu przciwdziałać, zaczęli zakładać oddziały samoobrony. Aby nie dopuścić do zaostrzenia sytuacji, potrzebna była interwencja władz państwowych wysokiego szczebla. Władze miejscowe nierzadko bowiem przymykały oczy na samowolne przywłaszczanie ziemi przez miejscowych „kułaków” (przykład rejonu trostjanieckiego). Przedstawiciel KOMZET-u z Moskwy N. Straszun zwrócił się z oficjalną skargą do chersońskiego sądu okręgowego, prosząc o niezwłoczne ukaranie winnych ${ }^{12}$.

Ogółem w latach 1924-1925 zaczęło uprawiać ziemię 2518 rodzin żydowskich. Przesiedleńcy ci byli skupieni w 140 kolektywach na Chersoniu i w 12 w rejonie Krzywego Rogu $^{13}$. Przedstawiciel Agro-Joint prof. A. Fabrikant, który wiosną 1925 r. wizytował żydowskie kolektywy, tak konstatował: „W analizie układu gospodarstw żydowskich, które tylko co zaczęły się rozwijać, łatwo zaobserwować oznaki mądrego podejścia do sprawy

${ }^{12}$ CGAWO, f. 505, op. 1, d. 113, 1. 106.

${ }^{13}$ Ibidem, f. 413, op. 1, d. 10, 1. 106. 
upraw"14. Oficjalnie pozytywnie ocenił stosunek władz sowieckich do problemu ludności żydowskiej w ZSRS i jej agrykulturyzacji. Jego dokładne sprawozdanie zostało przesłane do I sekretarza CK KP(b)U L. Kaganowicza. Niezależnie od wysokiej oceny poziomu gospodarstw żydowskich istniały ostre problemy aprowizacyjne przesiedleńców. Aktywny członek Agro-Joint dr Braun donosił: „W czasie podróży po Rosji rozmawiałem z setkami kolonistów i nie słyszałem, żeby ktoś się żalił, chociaż rozumiałem, że większa część z nich musiała przeżyć do pierwszych zbiorów na suchym, czarnym chlebie"15.

W pierwszym roku przesiedleńcy starali się przede wszystkim obsiać swoją ziemię, a dopiero potem zajmowali się budową domów. Według projektu Centralnego KOMZET-u dla każdej rodziny przewidywano budowę tymczasowej ziemianki. Rychło jednak Agro-Joint, pozyskawszy przychylność ukraińskiego KOMZET-u, przygotował i przesłał do zaakceptowania przez Centrum w Moskwie swój projekt już pełnowartościowego domu, z dachem i strychem, droższego od ziemianki zaledwie o 30 rubli. Należy zaznaczyć, iż pokrycie dopełniających kosztów budowy brała na siebie organizacja Agro-Joint. Wiele wysiłku w opracowanie i wprowadzenie w życie nowego projektu włożył agronom S. Lubarski. Nie bacząc na wszystkie biurokratyczne przeszkody, do lata 1926 r. zbudowano wiele wygodnych domów i położono fundamenty pod następne. Osiedla żydowskie odróżniały się od innych tym, że budowa domów i pomieszczeń gospodarczych była przemyślana i odpowiadała potrzebom rolników. Agro-Joint musiał jednak nieustannie walczyć z bezustannie wzrastającymi dopłatami do kosztów budowy, domagając się uzasadnienia rozliczeńn ${ }^{16}$.

Próbując zwięźle podsumować ten pierwszy okres agraryzacji ludności żydowskiej na Ukrainie, można stwierdzić, iż gospodarstwa były w pełni rentowne i miały dzięki pomocy odpowiednich organów państwowych i żydowskich organizacji zagranicznych dobre perspektywy. Ogółem w latach 1924-1928 oddano do użytku 9526 zagród. Według danych z 1928 r. na sto rodzin nowych osadników przypadało sześćdziesiąt domów. Biorąc pod uwagę obszar zasiewów przypadających na każde gospodarstwo żydowskie, sięgał on 11,6 ha, z czego połowę zajmowały zboża ozime. Według osób oceniających rezultaty osadnictwa żydowskiego do rolniczych sukcesów w znacznej mierze przyczyniło się tworzenie od samego początku gospodarstw kolektywnych. Organizacje, które finansowały kampanię, przede wszystkim Agro-Joint, podkreślały, że łatwiej było w kolektywach tworzyć towarzystwa kredytowe i łożyć na różne kierunki działalności rolnej w celu osiągnięcia wyższej wydajności produkcji. Kolektywne formy gospodarowania pozwoliły żydowskim rolnikom przejść do wielopolówki, wprowadzić progresywne metody intensywnej uprawy, wykorzystując pomoc agronomiczną, i od początku zakładać swoje gospodarstwa na podstawach towarowych. W pierwszym okresie najbardziej rozpowszechnione były proste formy wspólnot przesiedleńczych, np. towarzystwa wspólnej obróbki ziemi. Towarzyszyły im towarzystwa maszynowe i traktorowe, mleczno-towarowe, zapomogowe i kredytowe. Należy zaznaczyć, iż w miarę umacniania się gospodarstw zaczął zachodzić proces ich przegrupowywania, a nawet wyodrębniania gospodarstw indywidualnych. Był to niejako naturalny porządek rzeczy, gdyż na pierwszym etapie kolektywy były zakładane pospiesznie, bez liczenia się z czynnikami społecznymi i psychologicznymi, z interesami poszczególnych rodzin, które powinny gwarantować stabilny stosunek do uprawy roli. Niektórzy przesiedleńcy zaczęli patrzeć w przeszłość, na poprzedni styl i warunki życia, inni byli zachwyceni nową rolą społeczną,

\footnotetext{
${ }^{14}$ Centralnyj Gosudarstwiennyj Archiw Obszczestwiennych Organizacji Ukrainy (dalej CGAOO), f. 1, op. 20, d. 2020, 1. 42.

${ }_{15}$ Ibidem, 1. 82.

${ }^{16}$ Ibidem, d. 2784, 1. 94.
} 
szukali podobnych sobie i na tej podstawie przegrupowywali się i formowali nowe kolektywy. Te przegrupowane gospodarstwa charakteryzowały się wysokim poziomem inicjatywy, staranności i kultury rolnej.

Przedstawiciel Ukraińskiego KOMZET-u Winnikow na obradach CK KP(b)U w 1928 r. mówił: „Osobiście byłem na Chersońszczyźnie w 1925 r., w okresie, kiedy przesiedleńcy tylko co przyjechali, i byłem teraz, byłem świadkiem tego, jak w tych pustynnych, pozbawionych wody miejscach zaczęły wyrastać nowe osady, zaczęto wprowadzać nowe, lepsze metody gospodarowania niż w sąsiednich gospodarstwach ukraińskich. Ostatni przegląd działek i ludności miejscowej, przeprowadzony przez delegacje robotników i komisarzy na czele z Narodowym Komisarzem (narkomem) Szlichterem, tylko potwierdziły, że żydowskie przesiedlenie z gospodarczego punktu widzenia w pełni się opłaciło i nie zawiodło oczekiwań"17.

W końcu lat dwudziestych liczba żydowskich rolników na Ukrainie przekraczała już 100 tys. Należy tu uwzględnić 5151 żydowskich gospodarstw winogronowych i zbożowych, które do 1930 r. zaczęły funkcjonować w jej krymskiej części. Obejmowały one 141928 ha, posiadały 405 traktorów i 4 tys. ciężarówek oraz wiele bydła, w tym ponad 85 tys. krów. $\mathrm{Z}$ początkiem lat trzydziestych, zgodnie z ogólną polityką kolektywizacji rolnictwa, zaczęto je grupować w kołchozy. Większość kolonistów odnosiła się do tych poczynań krytycznie. Do końca 1931 r., pod silnym naciskiem Jewsiekcji i KOMZET-u, zdołano skołchozować aż 95 proc. gospodarstw. W porównaniu z innymi narodowościami Ukrainy był to wskaźnik najwyższy. Dla mniejszości niemieckiej wynosił on 79 proc., bułgarskiej — 78,5 proc., greckiej - 74,2 proc. Przyczyn tak szybkiego przejścia do gospodarki kołchozowej ludności żydowskiej było kilka. Przeważyła jednak wizja głodu będąca rezultatem nieurodzaju. Dotknął on zwłaszcza nowych przesiedleńców ulokowanych na gorszych obszarach, pozostałych po obdzieleniu ziemią miejscowych gospodarzy, którzy pozyskali lepsze przydziały. Połączenie gospodarstw rolników w kołchozy miało złagodzić kłopoty z żywnością. Mimo przystąpienia do scalania ziemi zewsząd jednak płynęły doniesienia o braku zapasów ${ }^{18}$. Na ich podstawie kierownik Jewsiekcji CK KP(b)U sporządził do władz zwierzchnich alarmującą notatkę: „[...] $\mathrm{Na}$ żydowskich przesiedleńczych fondach stworzyło się w większym stopniu ciężkie położenie. Ludzie w sensie dosłownym głodują. Znaczna część rodzin już od tygodni żywi się odpadkami. Całej ludności żydowskiej grozi katastrofa" ${ }^{\text {" }}$.

Po przeprowadzeniu masowej kolektywizacji władze zamiast pomóc kołchozom „stanąć na nogi” i okrzepnąć, zastosowały politykę dalszego czerpania zysków, dosłownie grabieży. Kołchozy zobowiązane były płacić wysokie podatki i wypełniać rosnące z każdym rokiem plany dostaw zbóż. Jeśli w 1929 r. kołchoźnicy zobowiązani byli dostarczyć 4,74 centnary z hektara, to dwa lata później już 6 centnarów. Należy przy tym zaznaczyć, że plany dostaw zbóż nie uwzględniały nieurodzajów i wiele gospodarstw nie było w stanie ich wypełnić.

W latach 1932-1933 normy wzrosły tak bardzo, że w wielu kołchozach nie było ziarna na pokrycie własnych potrzeb. Nie bacząc na tak dramatyczną sytuację, przedstawiciele KOMZET-u i władz miejscowych chodzili po domach i zabierali resztki. W żydowskich gospodarstwach nastał głód.

Nie licząc się z ludźmi, a dbając jedynie o zaspokojenie potrzeb państwa, na posiedzeniach rejonowych komitetów wykonawczych (rajispołkomow - zarządów powiatowych) sformułowano jednakowo brzmiące wnioski. Na przykład 17 IX 1932 r. na posiedzeniu w re-

\footnotetext{
${ }^{17}$ Ibidem, f. 1 op. 20, d. 2784, 1. 98.

${ }_{18}$ Archiw Centralnogo Komiteta Komunisticzeskoj Partii Ukrainy (dalej CK KPU), f. 1, op. 20, d. 2689,

1. $11-12$.

${ }^{19}$ Ibidem, 1. 17.
} 
jonie nowo-złotopolskim, analizując ,,przebieg żniw i wypełnienie planu dostaw żniwnych”, odnotowano, że „kołchozy znacznie naruszyły dyrektywy partii i rządu, aby zmniejszyć straty, nie mobilizują wszystkich sił i możliwości zbioru zbóż”. Wniosek końcowy brzmiał jednoznacznie: „Przekazać odpowiednim władzom sprawę arteli «Soc-Dorf» i pociągnąć do odpowiedzialności zarząd za dopuszczenie do skandalicznych strat w zbiorach [...] Odnotować przestępcze wykorzystanie maszyn podczas wywózki chleba ze strony kierownika komuny «Ernes» towarzysza Xhodosa i kierownika artelu «Dzierżyńskiego» towarzysza Wajsmana. Ich działania zostały ocenione jako umyślne zatrzymanie wypełnienia planu dostaw zbożowych" ${ }^{20}$. Chcąc podwyższyć dalekie od planowanych dostawy zbóż, władze zabierały całość plonów i jednocześnie zakazywały wydawania jakichkolwiek zaliczek w naturze wszystkim kołchozom, które nie wypełniły planów rocznych. Komitetom wiejskim (Sielsowietom) polecono zorganizować zbiór u poszczególnych kołchoźników i we wskazanych gospodarstwach [...] w pierwszej kolejności konfiskatę przeprowadzić u próżniaków, zdzierców i zdeklasowanego elementu, mającego małą ilość dni pracy [...] Umieścić kołchozy na czarnej liście z konfiskatą wszystkich gotowych artykułów przemysłowych i zaprzestaniem dalszego zawozu towarów. Nałożyć karę na wskazane kołchozy, np. na żydowski kołchoz im. K. Libknechta celem dostarczenia dodatkowego mięsa dla państwa [...] Co się tyczy żydowskiego kołchozu «Forojs», zastosować, co następuje:

- zabrać wszystkie zapasy, oprócz nasion na zasiew

— uprzedzić, że jeśli w najbliższych dniach nie będzie zdecydowanego przełomu w wypełnieniu planu, to zapadnie decyzja o zamianie dostaw zbóż na rzecz wypełnienia planu dostaw mięsa

- kierownika tego kołchozu oddać pod sąd za sabotaż dostaw”21.

Przez pięć dni obradował Nowo-Złotopolski RIK, rozpatrując sprawy żydowskich kołchozów „Krasnyj Biesarabiec” i „Fojtier Pojer”. 18 grudnia wydał postanowienie odnośnie do kołchozu „Krasnyj Besarabiec”:

— „wszystkie naturalne zapasy oprócz nasion na zasiew oddać w celu wypełnienia planu dostaw,

— zebrać bezprawnie rozdane kołchoźnikom zboże (jako awans w naturze) i zaliczyć go na poczet wypełnienia dostaw. Zwrot bezprawnie rozdanego zboża przeprowadzić w pierwszej kolejności u członków zarządu kołchozu,

- ujawnić winnych bezprawnego wydania zboża i pociągnąć do odpowiedzialności sądowej"22.

Podobne drakońskie kroki zostały podjęte w stosunku do kołchozu „Fojter Pojer”. Zobowiązano zarząd obwodowy (oblispołkom) do:

— „umieszczenia kołchozu na czarnej liście ze wszystkimi wynikającymi stąd konsekwencjami,

- przeprowadzenia w kołchozie zwrotu bezprawnie rozdanego kołchoźnikom zboża tytułem zaliczek w naturze,

- niezwłocznego aresztowania i oddania pod sąd kierownika kołchozu towarzysza Kosiewa i rachmistrza towarzysza Ejdelmana"23.

Choć następstwa masowej grabieży kołchozów były tragiczne, tylko w pewnej mierze znalazły odbicie w prasie tego okresu. Charkowska gazeta „Der Sztern” pod nagłówkami

${ }^{20}$ CGAOR Ukrainy, f. 1, op. 8, d. 311, 1. 319-329.

${ }^{21}$ Ibidem, 1. 305-306.

${ }^{22}$ Ibidem, 1. 302.

${ }^{23}$ Ibidem, 1. 299. 
Głodujące rodziny donosiła o braku chleba w żydowskich kołchozach Chersończszyzny ${ }^{24}$. W marcu pisano: „W wielu kołchozach rejonu plany dostaw za ubiegłe dwa lata do tego czasu są niewypełnione. Te gospodarstwa nie są przygotowane do siewu"25.

Jesienią 1932 r. odnotowano krytyczne położenie dwudziestu gospodarstw żydowskich znajdujących się w rejonach dolinskim, mierznickim i nowoprażskim obłasti dniepropetrowskiej, miropolskim, sernenowskim i czernuchowskim obłasti charkowskiej oraz zinowiewskim i nowodmitrowskim obłasti odeskiej. Wiele żydowskich kołchozów wyszczególniono w postanowieniu SNK (Rady Komisarzy Ludowych) z 21 V 1932 r. jako poszkodowane z powodu głodu.

W notatce winnickiego obkomu parti $O$ trudnościach aprowizacyjnych $w$ obłasti $i$ udzieleniu pomocy głodującej ludności z 18 III 1933 r. napisano, że „w Czudnowie w szkole żydowskiej miały miejsce dwa przypadki śmierci dzieci z głodu [...] Jeszcze gorsze jest położenie zdeklasyfikowanej biedoty żydowskiej w miasteczkach obłasti, wśród której niemało jest przypadków opuchlizny głodowej i śmierci z głodu"26. Jeszcze bardziej tragiczne w swej wymowie jest zestawienie sektora informacyjnego CK KP(b)U: „W stalindorfskim rejonie położenie kołchoźników żydowskich jest rozpaczliwe. Ludzie przestali prosić o pomoc, leżą W zimnych, nieopalanych domach i czekają na śmierć. W worosziłowskim sielsowiecie odnotowano 14 wypadków śmierci głodowej. W tym sielsowiecie u kołchoźnika Brawiermana leży czwórka dzieci w wieku od 5 do 10 lat, opuchnięte, z odkrytymi ranami, co świadczy o tym, że one gniją za życia"27.

Mimo wielkiej tajności o głodzie w żydowskich miasteczkach i kołchozach, pozbawionych centralnego zaopatrzenia w żywność, wiedziano w wielu krajach. Pisały o nim m.in. gazety w Polsce i USA. Przedstawiciele żydowskich organizacji z Polski, Stanów Zjednoczonych, Francji i Anglii starali się pomóc głodującym i zwracali się do władz ukraińskich z prośbami o zgodę na ich przyjazd. Jednak za każdym razem przedstawiciele partii i rządu zapewniali, że żadnego głodu nie ma i zezwolenia na wjazd nie udzielano.

Wiosną 1933 r. umierali z głodu mieszkańcy wsi i miasteczek w okolicach Berdyczowa, Żytomierza, Humania, Białej Cerkwi, Fastowa, Proskurowa, zamieszkiwanych głównie przez Żydów.

W latach 1934-1937 winą za tragiczną sytuację obwiniono najpierw działaczy AgroJontu, a następnie prawie wszystkich aktywistów KOMZET-u. Wszyscy oni byli represjonowani. Zarzucono im nieumiejętne kierowanie kolektywami przesiedleńców żydowskich, sabotaż i wrogą działalność. Do tego czasu liczba żydowskich arteli rolniczych na Ukrainie zmniejszyła się o ponad 30 proc., a liczba rolników ponaddwukrotnie. Odnotowane w okresie kolektywizacji i „,wielkiego głodu” załamanie osadnictwa żydowskiego na Ukrainie dopełniło losów tak obiecującej na początku polityki ,produktywizacji” ludności żydowskiej. Zakończenie historii gospodarstw żydowskich na Ukrainie dopisała druga wojna światowa. Przestały wówczas istnieć nawet te nieliczne, których mieszkańcy przetrwali lata głodu ${ }^{28}$.

24 „Der Sztern”, 8 II 1932.

25 Ibidem, 12 III 1932.

${ }^{26}$ Golod 1932-1933 rokiw na Ukraini oczima istorikiw i mowoju dokumentiw, Kiiw 1990, s. 450-452.

${ }^{27}$ Ibidem, s. 450-452.

${ }^{28}$ Dzieje osadnictwa żydowskiego na Ukrainie miały swoją kontynuację w Birobidżanie. Omawianie argumentów, które zadecydowały o wyborze Kraju Chabarowskiego na kolonizację rolną, wykracza jednak poza ramy tego artykułu. W wielkim skrócie można powiedzieć, iż decyzja o utworzeniu Żydowskiego Obwodu Autonomicznego świadczyła o pozytywnym nastawieniu do ZSRś opinii światowej. Była odpowiedzią na burżuazyjny projekt utworzenia w Palestynie państwa żydowskiego. Powstanie na tych terenach obwodu miało być wręcz symbolem realizacji idei „proletariackiego Syjonu”, 
Starając się podsumować dziesięcioletni okres osadnictwa żydowskiego na Ukrainie, można powiedzieć, iż o przebiegu kolonizacji najlepiej świadczy liczebność i obszar gospodarstw żydowskich oraz główne uprawy i hodowla, gwarantujące ich rentowność. Nowo osiedlona ludność żydowska, niemająca ugruntowanych nawyków w pracy na ziemi, intensyfikowała bowiem produkcję rolniczą, a nawet stopniowo spłacała kredyty. Do jej sukcesów w gospodarowaniu oprócz determinacji w przystosowaniu się do trudnych warunków bytowych w znacznej mierze przyczyniły się regulacje prawne, które umożliwiły dostęp organizacji zagranicznych. W związku z brakiem państwowych środków pieniężnych wykonanie odgórnie ustalonych planów stało się możliwe dzięki pomocy finansowej pochodzącej $\mathrm{z}$ zewnątrz.

Mimo końcowego niepowodzenia, będącego w znacznej części wynikiem odgórnych wymagań władz (spowodowanego rozmaitymi przyczynami) realizacja polityki kolonizacji rolnej tej mniejszości w pewnej mierze zmieniła utrwalony w społeczeństwie sowieckim stereotyp Żyda - handlarza i wyzyskiwacza. Umożliwiła pokazanie m.in. na przykładach pomocy sąsiedzkiej, nierzadko międzyetnicznej, że podziały na dobrych i złych, pracowitych i pasożytów nie przebiegają na płaszczyźnie narodowej, lecz mają wyznaczniki o wiele bardziej skomplikowane, często łamiące wygodne stereotypy. Ukazanie jej sukcesów, umiejętność współdziałania i współżycia z innymi nacjami ZSRS pokazuje zarazem ewolucję jej postrzegania w szerokim kontekście społecznym, kulturowym i politycznym.

\section{Rural Settlements of the Jewish Population in Ukraine in 1924-1934 (General Remarks)}

The history of the Jewish population in Russia and, subsequently, the Soviet Union constitutes a special page in the history of that state. One of its lesser-known aspects are the rural settlements of this minority in Ukraine, a fragment of a widely conceived national integration policy devised by the Soviet state. The course of the colonisation and, upon numerous occasions, its success are best evidenced by data cited in the study and pertaining to the number of settlers, the area of Jewish farmsteads, chief crops, and animal husbandry. It appears that the newly settled Jewish population, unaccustomed to work on the land, not only intensified agriculture but gradually even paid back credits. The profitability of the farmsteads was to a considerable extent favoured not solely by a determination to adapt to difficult living conditions but also by regulations permitting the access of foreign organisations. Owing to the absence of state funds the realisation of plans made at the top was rendered possible by foreign financial assistance.

Despite the ultimate failure of the undertaking, which was to a considerable measure the outcome of the demands made by the authorities, the accomplishment of rural colonisation by this particular minority to a certain degree altered the stereotype of the Jew conceived as a trader and an exploiter, embedded in Soviet society. It also made it feasible to show, i.a. upon the example of neighbourly help often involving assorted ethnic groups, that divisions into good and bad citizens, and into industrious members of society and parasites, do not coincide with national boundaries, but possess much more complicated determinants, often shattering convenient stereotypes. A successful demonstration of the ability to cooperate and coexist with other nations within the USSR simultaneously defined the evolution of its perception within a wide social, cultural, and political context.

komunistyczną repliką na koncepcję państwa „narodu wybranego” ukształtowaną na gruncie myśli nacjonalistycznej i judeo-religijnej. 